11. Самчук Л. І. Створення електронних бібліографічних посібників в дерсжавній науково-педагогічній бібліотеці України імені В. О. Сухомлинського / Л. І. Самчук // Вісник ОНУ. - Одеса : ОНУ, 2018. - Т. 23. - № 1. - С. 179-186. - (Серія: Бібліотекознавство, бібліографознавство, книгознавство). URL: http://vislib.onu.edu.ua/article/view/122671/131849 (дата звернення: 20.08.2019).

12. Складання бібліографічних посібників : інформ.-метод. матеріали / уклад. О. Галганова ; наук. ред. В. Кононенко. - Київ, 2015. - 80 с.

13. Стельмах Н. Інформаційно-бібліографічне забезпечення наукових досліджень із питань дошкільної освіти / Н. Стельмах // Вісник Книжкової палати. 2009. - № 7. - С. 18-21.

14. Трачук Л. Ф. Вебліографічні посібники бібліотек як джерела електронного довідково-бібліографічного обслуговування / Л. Ф. Трачук // Бібліотечний вісник. - 2011. - № 5. - С. 29-35.

15. Швецова-Водка Г. М. Вступ до бібліографознавства : навч. посіб. для студ. вищ. навч. закл. / Г. М. Швецова-Водка. - Київ : Кондор, 2004. $217 \mathrm{c}$.

Дата надходження до редакиї: 05.09.2019 р.

Володимир ЛАВРЕНЧУК, кандидат філологічних наук, дочент, завідувач кафедри суспільно-гуманітарної освіти Рівненського ОІППО

Марія ЛАВРЕНЧУК,

методист кабінету суспільно-гуманітарних предметів Рівненського ОІППО

\title{
ЦІННІСНІ КОНЦЕПТИ ВАСИЛЯ СУХОМЛИНСЬКОГО В КОНТЕКСТІ НОВОЇ УКРАЇНСЬКОЇ ШКОЛИ
}

\begin{abstract}
У статті проаналізовано концептуальні засади Нової украӥнської школи у суголоссі із філософськометодологічними концептами педагогічної спадщини В. Сухомлинського. Звернено увагу на такі иіннісні кониепти видатного педагога, як людиночентризм; дитиноцентризм; сповідування сімейних иінностей; иіннісний концепт слова, мови, літератури, мовної картини світу; кордоцентризм.
\end{abstract}

Ключові слова: концепт, иінності, Нова украӥнська школа, емпатія, кордоцентризм.

В статье проанализированы кониептуальные основы Новой украинской школь в сравнении с философско-методологическими кониептами педагогического наследия В. Сухомлинского. Выделены такие иенностные концепты выдающегося педагога, как человекоиентризм; ребенкочентризм; исповедание семейных иенностей; иенностный кониепт слова, языка, литературы, языковой картины мира; кордоиенттизм.

Ключевые слова: концепт, ценности, Новая украинская школа, эмпатия, кордочентризм.

The article is concerned with the concept of values of Vasyl Sukhomlynsky's inheritance. The authors analyze this issue in the context of the conceptual approaches of the New Ukrainian School. The concept is considered as an innovative idea that includes the content and the gist of the modern education. Referring to the new Education Regulations, namely the concept of the New Ukrainian School, the Law of Ukraine on Education, the authors come to the conclusion that the concept of values in the Vasyl Sukhomlynsky's teaching principles formed the basis for the concept of the New Ukrainian School and other Education Regulations. The given examples illustrate the maintaining of the continuity of the attitude to the concept of values of the famous pedagogue with the concept of values of the modern education in Ukraine and all around the world. The article deals with such concepts of values as happiness, empathy, childcentrism, Philosophy for children, I-Concept, and holistic perception of the language picture of the world.

According to Vasyl Sukhomlynsky, formation of emotional intelligence is a holistic system of development, upbringing and education that is based on the humanistic ideas of goodness and beauty.

Language and literature, as school subjects, are the source of morality and spirituality that cherishes the human virtues and eternal values. They develop the key competencies and the holistic perception of the world.

The language code identifies the national authenticity, uniqueness and consolidates the speakers for the evolution and sustainability.

Key words: concept, values, New Ukrainian School, empathy, philosophy for children, language picture of the world, eternal values, heart-centered philosophy. 
Постановка проблеми. Педагогічна спадщина видатного педагога-гуманіста Василя Олександровича Сухомлинського - це передусім наука про духовні цінності: моральні, естетичні, сповідування принципів гуманізму, дитиноцентризму, мультикультуралізму та толерантності. Цьому має передувати тривалий, багаторічний процес виховання з метою підготовки маленької людини до усвідомлення означеної гуманістичної істини. Про ціннісно-гуманістичну, духовну, морально-етичну спрямованість педагогічної спадщини Василя Сухомлинського свідчать вже самі назви його праць: «Серце віддаю дітям», «Шлях до серця дитини», «Духовний світ школяра», «Людна - найвища цінність», «Моральні цінності сім’ї», «Людина неповторна», «На нашій совісті людина», «Як виховати справжню людину», «Моральні заповіді дитинства і юності», «Обережно: дитина!», «Щоб душа не була пустою» та ін.

Актуальність досліджуваної проблеми зумовлена необхідністю переходу до нової за змістом і формою української школи, яка насамперед покликана формувати життєві компетентності та систему цінностей вихованців. Про це йдеться і в основних документах про освіту, серед яких - Концепція «Нова українська школа», новий Закон України «Про освіту», Державний стандарт початкової освіти.

Аналіз наукових досліджень і публікацій. У визначенні оптимальних умов формування ціннісних орієнтацій опираємося передусім на розробки у контексті сучасних мовознавчих, літературознавчих, філософських та культурологічних концепцій (О. Авраменко, Є. Волощук, В. Гладишев, Н. Голуб, О. Глазова, В. Звиняцковський, Ю. Султанов, Б. Шалагінов); інноваційних форм викладання мови та літератури (O. Icаєва, Ж. Клименко, Л. Мірошниченко, О. Куцевол, О. Ніколенко, В. Гладишев, В. Шуляр); діалогічної природи взаємодії культур (В. Доманський). Означені теоретичні засади дають змогу розробити ефективну методику формування ціннісних орієнтацій.

Серед сучасних українських дослідників, що всебічно дослідили творчу спадщину українського педагога-новатора, - М. Антонець, Н. Безлюдна, I. Бех, А. Богуш, Л. Бондар, В. Деркач, Н. Дічек, І. Зязюн, А. Іванко, Н. Калініченко, В. Кравцов, В. Кушнір, М. Левківський, М. Каргапольцева, Т. Кочубей, О. Петренко, Г. Пустовіт, О. Савченко, М. Скрипник, М. Сметанський, О. Сухомлинська та ін.

Зважаючи на головні постулати Концепції Нової української школи, в якій визначено, що ціннісний підхід має бути наскрізним у навчанні всіх базових предметів, з'явилася необхідність звернутися до педагогічної спадшини Василя Сухомлинського більш грунтовніше.

Мета статті - дослідити ідеї Василя Олександровича Сухомлинського щодо ціннісних концептів, які реалізуються в контексті Концепції «Нова українська школа».

Виклад основного матеріалу. Найважливішим показником якості освіти є духовний світ розвинутої особистості, а найважливішим елементом їі духовного світу - ціннісні орієнтації як форма відображення особистісних цінностей. Плекання високоосвіченої, патріотичної, інноваційної всебічно розвиненої, успішної особистості - основна мета сучасної освіти.

Як зазначено в проєкті Державного стандарту базової середньої освіти, «метою сучасної освіти $\epsilon$ всебічний розвиток, навчання, виховання здобувачів освіти, виявлення їх обдарувань, розвиток талантів, здібностей, компетентностей та наскрізних умінь, необхідних для соціалізації, свідомого життєвого вибору, самореалізації, відповідальності, трудової діяльності та громадянської активності, дбайливого ставлення до родини, власної країни та довкілля» [2].

Реалізація мети базової середньої освіти грунтується на таких ціннісних орієнтирах:

1) визнання обдарованості кожної особистості, що забезпечується рівним доступом до освіти, забороною будь-яких форм дискримінації або відокремлення здобувачів освіти на основі попереднього відбору;

2) радість пізнання, що зумовлюється використанням в освітньому процесі дослідницької та проєктної діяльності;

3) розвиток вільної особистості через підтримку самостійності, незалежного мислення та впевненості в собі;

4) здоров'я та добробут шляхом формування здорового способу життя і створення умов для гармонійного фізичного та психоемоційного розвитку;

5) безпека, завдяки створенню атмосфери довіри і взаємоповаги, перетворенню закладу освіти на безпечне місце, де запобігають насильству і цькуванню (булінгу);

6) утвердження людської гідності через виховання чесності, відваги, наполегливості, доброти, справедливості;

7) плекання любові до рідного краю, української культури;

8) формування активної громадянської позиції та шанобливого ставлення до України як держави [2].

Зважаючи на Концепцію Нової української школи, до основних иіннісних концептів віднесено: Я-концепцію; концепт дитиноцентризму; концепт цілісної картини світу; концепт мови, літератури, слова; концепт батьківщини, родини, довкілля та ін. [4].

Концептуальні засади Нової української школи контекстуально окреслилися через суголосся із філософсько-методологічними концептами педагогічної спадщини В. Сухомлинського, найважливішими 3 яких $\epsilon$ : людиноцентризм («Людна - найвища цінність», «Людина неповторна», «На нашій совісті людина», «Як виховати справжню людину»; дитиноцентризм («Серце віддаю дітям», «Шлях до серця дитини», «Духовний світ школяра», «Моральні заповіді дитинства і юності», «Обережно: дитина!», «Щоб душа не була пустою»); сповідування сімейних цінностей («Моральні цінності сім’і»); ціннісний концепт Слова, Мови, Літератури, мовної картини світу; кордоцентризм та ін.

Звернімося до концепту «інноватор», який у Концепції «Нова українська школа» [4] передбачає «здатність особи до сталого розвитку, долання труднощів та реагування на зміни, відкритість до нових ідей, ініціювання змін у близькому середовищі (клас, заклад освіти, громада тощо), спроможність визначати й ставити перед собою цілі, мотивувати себе та розвивати в собі стійкість і впевненість, щоб займатися навчанням упродовж усього життя та досягати успіхів у ньому». У контексті досвіду Павлиської середньої школи В. Сухомлинський надає низку порад і рекомендацій зі створення «близького», комфортного освітнього середовища, вдосконалення змісту, форм і методів формування у вихованців загальнолюдських духовних цінностей, становлення всебічно розвиненої особистості, здатної до навчання впродовж життя та іiі прагнення повсякчас бути успішною [12]. 
Гуманна педагогіка, про яку чимало написано в працях Сухомлинського, має стати не лише експериментальною практикою, практикою вчителів-новаторів і творчих учителів, а канонічною й повсякденною.

Варто зауважити, що Нова українська школа базується передусім на засадах емпатії та формуванні емоційного інтелекту, тобто окреслює концепт емпатії. Психологи так трактують значення терміна «емпатія»: ірраціональне розуміння іншої особистості, відчуття ії внутрішнього світу, вміння частково випробувати ті ж емоції, що й у співрозмовника, одночасно відокремлюючи їх від власного сприйняття. При цьому вони виокремлюють емоиійну (побутову) емпатію (форма розумової діяльності, що заснована на проєктуванні та наслідуванні реакцій іншої людини, коли одна людина бачить почуття співрозмовника і проєктує їх на себе) й когнітивну емпатію (не лише вміння емоційно сприймати почуття іншої людини, а й здатність інтелектуально аналізувати iї слова, дії i поведінку, тобто, по-іншому, розуміти людину).

Педагогічна спадщина В. Сухомлинського також базувалася на принципах емпатії й взаємоемпатії - концепті кордоцентризму, коли не лише вчитель відчуває емоційний стан учнів, а й учні відчувають емоційний стан учителя. Як приклад, можемо навести виховні ситуації, коли видатний педагог намагався проникнути в «найтонші, нерідко приховані людські відносини» [7], прагнув зрозуміти, якою має бути гармонія бажань і обов'язків, боровся 3 «глухотою серця» та «закритістю серця» [9], які пізніше викликали в нього особливі роздуми («Серце віддаю дітям», «Сто порад учителеві»).

Формування емоційного інтелекту, на думку видатного педагога, - це цілісна система розвитку, виховання та навчання, що грунтується на гуманістичних ідеях добра і краси, адже дитина пізнає навколишній світ здебільшого серцем. Тому в неї потрібно зберегти й розвинути чутливість до всього людського, насамперед чутливість у самій собі. Учень має пройти довготривалу школу відчуттів і сприймань, що виробить у нього широкий діапазон почуттів, співчуття, милосердя, любов і повагу до людини, особливо знедоленої. Він переконував, що в «дитини необхідно цілеспрямовано розвивати загальнолюдські якості та властивості особистості за допомогою педагогічно обгрунтованих шляхів та засобів» [9].

Саме мова і література, на нашу думку, є тим морально-духовним ресурсом, який допоможе плекати людські чесноти та вічні цінності, формувати важливі ключові компетентності, цілісне сприйняття світу. Адже саме мовний код ідентифікує національну автентичність, неповторність особистості, консолідуючи при цьому іiї носіїв, закликаючи до еволюції та сталого розвитку.

Тому рідна мова, а також світова культура та література $\epsilon$ ціннісним маркером для сучасного суспільства. У зв'язку з цим дослідниця О. Глазова відзначає, що «виховання національно свідомої мовної особистості неможливе без формування ціннісних орієнтирів» [1]. Формуючи мовну особистість, словесник впливає на формування мовної картини світу свого учня, частиною якої є ціннісна картина. Ціннісна (аксіологічна) картина світу - це комплекс найважливіших для нації та особистості оцінних суджень, що співвідносяться з правовими, релігійними, моральними кодексами, загальноприйнятими судженнями та уявленнями певної спільноти; складова не лише мовної, а й концептуальної картин світу, частина концептосфери сучасної української нації.

На думку Сухомлинського, слово як інструмент навчання має величезне значення. Звідси й правило, сформульоване і неодноразово повторюване педагогом: «кожен учитель, незалежно від того, який предмет він викладає, повинен бути словесником» [8, с. 78].

Термін «мовна картина світу» українські лінгвісти тлумачать як «представлення предметів, явищ, фактів, ситуацій дійсності, ціннісних орієнтирів, життєвих стратегій і сценаріїв поведінки в мовних знаках, категоріях, явищах мовлення, що є семіотичним результатом концептуальної репрезентації дійсності в етносвідомості» [5, с. 365].

На думку Л. Лисиченко, мовна картина світу складається 3 мовних одиниць, що виражають концепти, поняття, а також мовні способи і засоби вираження зв'язків, що наявні в концептуальній картині світу [3, с. 14].

Дбаючи про гармонійний розвиток моралі, розуму, почуттів своїх вихованців, Василь Олександрович переконував, що слово і краса - це «найтонші засоби впливу на юну душу». При цьому педагог висловлював думку, що «дитина лише тоді знатиме мову, коли разом зі змістом сприйматиме емоційне забарвлення» $[11$, c. 315$]$.

У формулі Нової української школи одним із ключових компонентів $€$ наскрізне формування цінностей. Зважаючи на це, зауважимо, що рівень володіння словом як педагогічним інструментом $є$ чи не найважливішою ознакою професіоналізму вчителя. Зокрема, предмети мова і література $є$ тим морально-духовним ресурсом, який допоможе плекати людські чесноти та вічні цінності, формувати важливі ключові компетентності, цілісне сприйняття світу. «Мовна культура, - за словами В. О. Сухомлинського, - це живодайний корінь культури розумової, усього розумового виховання, високої, справжньої інтелектуальності. Завдяки мові людині стають доступні найрізноманітніші джерела, що живлять емоційну, інтелектуальну й вольову сферу іiі духовного життя. У мові відбивається ідейна спрямованість духовного життя людини, слово містить у собі невичерпні можливості для впливу на її світоглядну сферу» [6].

Правильно і чисто розмовляти рідною мовою це не лише прерогатива вчених-лінгвістів, письменників чи вчителів-мовників, це обов'язок кожної культурної людини.

Висновки. Отже, стратегічний напрям розвитку сучасної системи шкільної освіти в Україні полягає в спрямованості на особистісно та компетентнісно орієнтовану освіту із наскрізним формуванням цінностей, тобто таку, в якій особистість учня перебуватиме в центрі уваги педагога, психолога, у якій освітня діяльність суб' єктів стане едукативним процесом виховання, розвитку та навчання.

Саме так вибудовується сучасна система освіти в Україні: «філософія для дітей», концепт дитиноцентризму розглядає освітній процес із позицій ціннісно-компетентнісного підходу, визначається здатністю вирішувати проблеми різної складності на основі здобутих знань, володіти способами діяльності, а також здатності учня застосовувати ці знання на практиці.

Для творчої праці В. О. Сухомлинського із дитячим колективом було характерно: використання різноманітних форм і методів організації освітньої діяльності, орієнтованої на конкретного учня; 
створення атмосфери зацікавленості кожної дитини в роботі класу; стимулювання дітей до висловлювань, використання різних способів виконання завдань без страху помилитися, дати неправильну відповідь; підтримка учня в його бажанні знаходити власний спосіб роботи (наприклад, у ході розв'язування задачі чи виконання вправи), аналізувати на уроці не лише свою роботу, а й інших учнів; створення на уроці умов для природного самовираження учня, а також таких педагогічних ситуацій, що дають змогу кожному учневі виявляти ініціативу, самостійність у роботі - саме це все вважаємо основними ознаками особистісно орієнтованого підходу у навчанні.

Виховати справжнього громадянина, патріота України можна лише через Серце, Душу, Любов, Красу. Саме у них приховується могутня сила протистояння загрозам національної безпеки у сфері освіти.

Творча діяльність і величезні заслуги В. Сухомлинського стають дедалі очевиднішими. І сьогодні ми повинні не лише пам'ятати про це, а й впроваджувати в сучасну педагогічну практику його ідеї та доробки.

\section{СПИСОК ВИКОРИСТАНОЇ ЛІТЕРАТУРИ}

1. Глазова О. Культура мовлення і сучасний інформаційний простір / О. Глазова // Українська мова і література. - 2009. - № 13 (24). - С. 37-38.

2. Державний стандарт базової середньої освіти : проєкт. URL: https://mon.gov.ua/ua/news/ ministerstvo-osviti-i-nauki-ukrayini-proponuye-dlyagromadskogo-obgovorennya-proyekt-derzhavnogostandartu-bazovoyi-serednoyi-osvit (дата звернення: 12.09.2019).
3. Лисиченко Л. А. Лексико-семантичний вимір мовної картини світу / Л. А. Лисиченко. - Х. : Вид. група «Основа», 2009. - 191 с.

4. Розпорядження Кабінету Міністрів України «Про схвалення Концепції реалізації державної політики у сфері реформування загальної середньої освіти «Нова українська школа» на період до 2029 року» від 14.12.2016 № 988-p. URL: https:/www.kmu.gov.ua/ua/ npas/249613934 (дата звернення: 10.09.2019).

5. Селіванова О. Сучасна лінгвістика: термінологічна енциклопедія / О. Селіванова. - Полтава : Довкілля. - К., 2006. - 716 с.

6. Сухомлинський В. Вибрані твори : в 5 т. / В. Сухомлинський. - К. : Радянська школа, 1976. - Т. 1.-С. 319.

7. Сухомлинський В. О. Серце віддаю дітям / В. О. Сухомлинський // Вибрані твори : в 5 т. - К. : Рад. школа, 1977. - Т. 3. - С. 9-279.

8. Сухомлинський В. О. Слово про слово / В. О. Сухомлинський // Вибрані твори: в 5 т. - К. : Рад. школа, 1977. - Т. 5. - С. 160-167.

9. Сухомлинський В. О. Сто порад учителеві / В. О. Сухомлинський // Вибрані твори: в 5 т. - К. : Рад. Школа,1976. - Т. 2. - С. 417-654.

10. Сухомлинський В. Статті / В. Сухомлинський // Вибрані твори : в 5 т. - К. : Радянська школа, 1977. Т. $5 .-639$ c.

11. Сухомлинський В. Я розповім вам Казку. Філософія для дітей / В. Сухомлинський ; [уклад. О. В. Сухомлинська]. - Харків : ВД «Школа», 2016. - 576 с.

12. Сухомлинський В. О. Павлиська середня школа / В. О. Сухомлинський // Вибрані твори : в 5 т. - К. : Рад. школа, 1977. - Т. 4. - С. 5-390.

Дата надходження до редакиіï: 23.09.2019 p.

Олена ПАВЛОВА,

учителька музичного мистеитва

К3 «Гімназія імені Т. Г. Шевченка»

Херсонської обласної ради,

аспірантка Херсонського державного університету

\section{АСПЕКТИ ПАРТНЕРСЬКОГО ПІДХОДУ В ПЕДАГОГІЧНІЙ СИСТЕМІ В. О. СУХОМЛИНСЬКОГО}

У статті розкрито значення наукової спадшчни В. О. Сухомлинського в навчально-виховному прочесі. Визначено окремі аспекти його педагогічної діяльності, покладені в основу Концепиії Нової украӥнської школи, зокрема обтрунтовано організачійно-педагогічні умови ефективного впровадження партнерського підходу; необхідність застосування діалогової стратегії та педагогічної взаємодії, яка може бути реалізована завдяки єдності інтелектуальноі діяльності, світоглядних переконань та творчої cnisnpaui.
Ключові слова: партнерський підхід, освіта, виховання, Нова украӥнська школа, профільне навчання, особистість, комунікація.

B статье раскрыто значение научного наследия В. А. Сухомлинского в учебно-воспитательном прочессе. Определены отдельные аспекты его педагогической деятельности, положеннье в основу Кониеепиии Новой украинской школь, в частности обоснованы организационно-педагогические условия эффективного внедрения партнерского подхода; 